Brazilian Journal of Political Economy, vol. 41, nº 4, pp. 797-814, October-December/2021

\title{
The reswitching of techniques and its epistemological implications: a deepening of criticism
}

\author{
O reswitching das técnicas e suas implicações \\ epistemológicas: um aprofundamento da crítica
}

ALAIN HERSCOVICI****

RESUMO: Este paper tem por objetivos (a) explicitar os mecanismos a partir dos quais é formulada a problemática do reswitching das técnicas e (b) analisar as implicações no que diz respeito à arquitetura geral da macroeconomia neoclássica. Mostrarei como esses elementos permitem refutar a teoria neoclássica da distribuição da renda, e porque eles se traduzem pela instabilidade do sistema. Em uma primeira parte, explicitarei os mecanismos que constituem os fundamentos microeconômicos da macroeconomia neoclássica; em uma segunda parte, apresentarei as diferentes modalidades de interpretações no que concerne ao reswitching das técnicas, e aprofundarei as críticas que o arcabouço neoricardiana permite formular em relação à construção neoclássica.

PALAVRAS-CHAVES: Reswitching das técnicas; distribuição da renda; instabilidade estrutural.

ABSTRACT: This paper aims (a) to explain the mechanisms from which the problem of reswitching of techniques is formulated and (b) to analyze the implications with regard to the general architecture of neoclassical macroeconomics. I will show how these elements allow refuting the neoclassical theory of income distribution, and why they translate into structural instability. In the first part, I will explain the mechanisms that correspond to the problem of reswitching of techniques; in the second part, I will study the implications linked to the reswitching, with regard to the determinants of income distribution and the equilibrium stability.

KEYWORDS: Reswitching of techniques; rent distribution; structural instability.

JEL Classification: B41; E11; E13.

\footnotetext{
* Full Professor, Department and Post-Graduation Program in Economics at the Federal University of Espírito Santo (UFES), Vitória-ES, Brazil. E-mail: alhersco.vix@terra.com.br. Orcid: https://orcid. org/0000-0002-0378-7561. Submitted: 11/March/2020; Approved: 29/October/2020.

* * Coordinator of the Grupo de Estudo em Macroeconomia (GREM) and Grupo de Estudo em Economia da Cultura, da Comunicação, da Informação e do Conhecimento (GEECICC), UFES, and Researcher at CNPq (National Council for Scientific and Technological Development).
} 
"The first question is whether there exists an aggregate production function in which quantities of labour and 'capital' explain both the level of the national product and, by means of the 'marginal products' of the two factors, its distribution. A second question is whether a similar production function can be conceived for any single commodity. The third and most important question concerns the basic premise of the traditional theory of distribution in all its formulations: the notion that a fall of $r$ will cheapen the more capital intensive processes of production."

(Garegnani, 1970)

This paper aims to (a) explain the mechanisms from which the problem of reswitching of techniques is formulated; (b) to analyze the implications with regard to the general architecture of neoclassical macroeconomics; and (c) to show how Sraffa and the neo-Ricardian school proposes an alternative solution. Contrary to the traditional neo-Ricardian view that conceives production prices as the long-term position that the system achieves, regardless of short-term fluctuations (Carvalho, 1983-1984), I will show why the system is intrinsically unstable, and to what extent this instability constitutes a deepening of the neo-Ricardian criticism, in relation to the neoclassical economy.

In the first part, I will explain the mechanisms that constitute the microeconomic foundations of neoclassical macroeconomics, the hypotheses on which these mechanisms are based, and their implications with regard to the nature of macroeconomic equilibrium and to the adjustment processes towards equilibrium.

In the second part, I will present the different modalities related to the reswitching of techniques. In this regard, I will highlight some logical flaws and thus deepen the criticisms that the neo-Ricardian framework allows formulating in relation to the neoclassical construction.

I will implement my analysis from two levels: the first one relates to a macroeconomic approach in which the economy is divided into two sectors, the one that produces capital goods and the one that produces consumer goods. The second level studies the reswitching of techniques; it is a microeconomic analysis, as it is about maximizing the firm's individual profit from the choice of techniques. In the neoclassical tradition, macroeconomics essentially has microeconomic foundations; thus, the refutation of these Marshallian fundamentals translates into the refutation of the aggregated macroeconomic models ${ }^{1}$. The deepening of the criticism elaborated in this paper lies in the fact that, due to the capital controversy, this transition from the micro to the macroeconomic level cannot be carried out on the basis of the same mechanisms.

\footnotetext{
${ }^{1}$ The systematization of the criticism elaborated by Sraffa (1960) is based on a previous criticism of the Marshallian microeconomic fundamentals (Sraffa, 1925, 1926).
} 


\section{I) THE ARCHITECTURE OF NEOCLASSICAL MACROECONOMICS}

1) The main causal relations of neoclassical macroeconomics.

The foundations of neoclassical macroeconomics can be expressed by the following propositions:

Income distribution is determined by the following equation (Denis, 1974, Deleplace, 2007):

$$
Y=r . C+w \cdot L
$$

( $r$ as the profit rate, $w$ as the wage rate, $Y$ as the product, $C$ and $L$ capital and labor quantities)

Equation (1), in per capita values, is equivalent to:

$y=k \cdot r+w$

$\mathrm{y}=\mathrm{Y} / \mathrm{L}$ and $\mathrm{k}=\mathrm{C} / \mathrm{L}$

that is:

$$
k=\frac{y-w}{r}
$$

Equivalent to:

$$
k=f(\mathrm{r})
$$

with $\mathrm{f}^{\prime}<0$

(3) and (3') define the substitution principle, valid for all values of $r$.

The rate of profit is equal to the marginal productivity of global capital:

$$
r=p m k=d y / d k
$$

From (2), it is possible to write:

$$
d y=r \cdot d k+k \cdot d r+d w
$$

Combining (4) and (5), we deduce that:

$-d w / d r=k$

\section{Proposition 1}

Relations (1) and (2) show that the distribution of income is determined by the quantity of factors used multiplied by their respective prices, the interest rate and the wage rate. How are these quantities and prices determined?

\section{Proposition 2}

The prices of factors of production are determined by matching marginal cost 
with marginal product, with marginal cost increasing and marginal productivity decreasing.

(6) highlights the fact that the abundance, or scarcity, of the production factor determines its price, which is explained by the law of decreasing marginal productivity and the equalization of the price of the production factor with its marginal productivity. I can define an equilibrium value represented by $\mathrm{k} *$. When $k>k *$, there is an abundance of capital. Due to the law of decreasing marginal productivity, the interest rate will decrease; from (6), we can deduce that dw/dr increases and, consequently, $-(\mathrm{dw} / \mathrm{dr})$ decreases, which translates into a decrease of $k$ towards its equilibrium value. When $k<k^{*}$, the same mechanisms work in the opposite direction: the scarcity of capital causes $d r$ to increase and $k$ to increase.

The convergence towards the equilibrium position is the result of the law of decreasing marginal productivity, which allows us to affirm that, starting from (6), the price of the factors of production is determined from its relative scarcity (or abundance). The relative quantities of the factors of production determine their prices. As Harris $(1978$, p. 219) writes, "The distribution of income is therefore completely determined by technology and "factors endowments" and "[...] relative factor prices reflect scarcity of the factors [...]".

Convergence towards the equilibrium position thus depends on the verification of the law of decreasing marginal productivity: the price of capital will decrease (increase) when it is abundant (scarce). Thus, the combined action of the law of decreasing marginal productivity and the substitution principle explains the process of convergence towards the equilibrium position.

However, when capital is not homogeneous, it is impossible to elaborate the very concept of marginal productivity and thus deduct the rate of profit. The rate of profit is equal to the marginal productivity of capital., which is equal to the ratio between the change in product and the change in capital. However, in order to know the product in value, it is necessary to know the profit rate in advance; consequently, in order to know the profit rate, it is necessary to know the same profit rate in advance (Garegnani, 1980, p. 11) ${ }^{2}$.

\section{2) The starting point of Neo-Ricardian criticism}

The main theoretical results of neo-Ricardian theory may be synthesized from the following example ${ }^{3}$ : we consider two commodities $\mathrm{A}$ and $\mathrm{B}$, each produced by capital $\mathrm{C}_{\mathrm{A}}$ and $\mathrm{C}_{\mathrm{B}}$, and some quantity of labor, $\mathrm{L}_{\mathrm{A}}$ and $\mathrm{L}_{\mathrm{B}}$. Obviously, $\mathrm{C}$ is expressed in labor quantity, in terms of indirect labor:

$$
L_{A}+C_{A}=L_{B}+C_{B}
$$

\footnotetext{
${ }^{2}$ In regard to another criticism of the marginalist approach, and more specifically the marginal productivity concept, see Marcuzzo and Rosselli (2011).

${ }^{3}$ In respect to a complete presentation, see Cohen and Harcourt (2003).
} 
In regard to the Ricardian labor theory, relation (7) implies that A value is equal to $B$ value:

$$
A=B
$$

Capital is conceived as labor "spent" in the past, as a "round-about method of production" (Hayek, 2009); it must get an economic return every period. The dated labor is evaluated, in each period, based on the current profit rate.

Figure 1: The Ricardian value theory

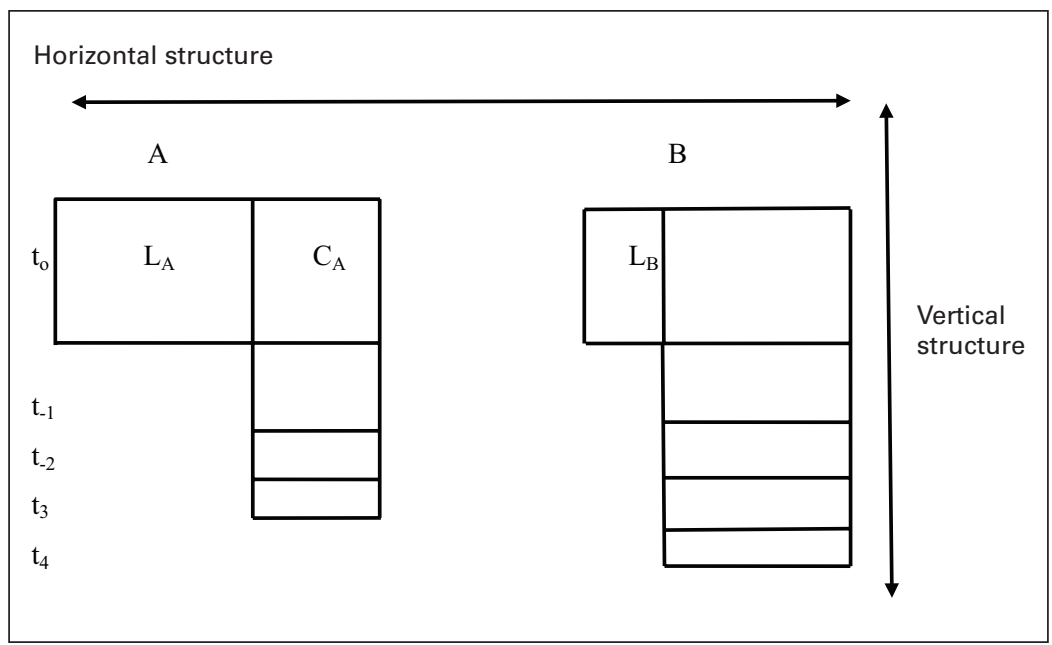

Fonte: Elaboração própria.

Relation (8) is verified only when the horizontal and the vertical structures are the same for A and B. It will be also verified when the profit rate is nil; notwithstanding, such solution is a no-sense, from an economic perspective. As there are no reasons for the horizontal and vertical structure being the same for the two commodities, A value is different from B value.

If we consider a high profit rate, $\mathrm{B}$ value will be greater than $\mathrm{A}$ value. As the wages rate increases (which means that profit rate decreases), B value will decrease in relation to A value: dated labor is updated from a smaller rate and current labor from a higher rate.

We can write:

$$
V_{B}=\gamma \cdot V_{A}
$$

equivalent to:

$$
\begin{aligned}
& \gamma=V B / V A \\
& \gamma=\varphi(w) \\
& \gamma^{\prime}<0 .
\end{aligned}
$$




\section{Proposition 3}

The value of a given quantity of aggregate capital depends directly on the value of the distributive variables. This applies equally to any type of commodity. In this regard, Robinson (1953-1954, p. 86) states that "Thus the same stock of physical goods represents a larger amount of real capital when the rate of interest is higher [...]."

\section{3) Stability, equilibrium instability and substitution principle}

The main results of the neo-Ricardian analysis show, without any ambiguity, that there cannot be a stable long-term equilibrium position that the system automatically reaches ${ }^{4}$. In his seminal work of 1953-1954, Robinson comes to this conclusion: "Now, the conditions of equilibrium require that the rate of interest which enters into the cost of equipment be equal to the rate of profit actually ruling [...]." (p. 94). Consequently, the stability of the equilibrium depends on the stability of the distributive variables: "An unforeseen fall in the rate of profit ruptures the conditions of equilibrium" (ibid., p. 100).

This principle can be applied to any type of market, and it necessarily translates into the instability of the meso and macroeconomic equilibrium. In this paper, I will illustrate this thesis based on the loanable funds' theory and the balanced growth models derived from Solow's model (1956).

\subsection{The loanable funds theory}

Macroeconomic equilibrium depends directly on the existence of the monotonic relationship between interest rate and capital: in the absence of such a relationship, the equalization between investment and savings is not systematically realized (Petri, 1998), and macroeconomic equilibrium is, by nature, unstable. This equilibrium is characterized by the fact that global demand is equal to global supply: global supply $\mathrm{Og}$ is equal to $\mathrm{C}+\mathrm{S}$ (consumption and saving), and global demand $\mathrm{Dg}$ to $\mathrm{C}+\mathrm{I}$ (consumption and investment). The macroeconomic balance corresponds to the following relationship:

$$
\mathrm{Og}=\mathrm{C}+\mathrm{S}=\mathrm{Dg}=\mathrm{C}+\mathrm{I}
$$

From (12), I deduce that $\mathrm{Og}>\mathrm{Dg}$ when $\mathrm{S}>\mathrm{I}$, and that $\mathrm{Dg}>\mathrm{Og}$ when $\mathrm{I}>\mathrm{S}$ :

$$
\mathrm{Og}-\mathrm{Dg}=\mathrm{S}-\mathrm{I}
$$

We can consider that the economy is divided into two sectors, sector 1 which produces the production goods and sector 2, the consumer goods. If $\mathrm{Dg}=\mathrm{D}_{1}+\mathrm{D}_{2}$ and $\mathrm{Og}=\mathrm{O}_{1}+\mathrm{O}_{2}$, starting from (13), I can write:

\footnotetext{
${ }^{4}$ This approach is intrinsically different from the "traditional" neo-Ricardian analyses that conceive Keynesian analysis as a short-term analysis, whereas long-term positions are defined by neo-Ricardian production prices, in the absence of path dependence. In this regard, see Garegnani, (1978-1979) Amadeo and Dutt (1987) and Cardim de Carvalho (1983-1984).
} 


$$
O_{1}+O_{2}-\left(D_{1}+D_{2}\right)=S-I
$$

That is:

$$
\left(O_{1}-D_{1}\right)-\left(D_{2}-O_{2}\right)=(S-I)
$$

(Oi and Di represent sector i supply and demand respectively)

Equation (15) highlights the conditions of stability of the macroeconomic equilibrium: when I = S, the global demand remains equal to the global supply. Sectoral disequilibrium is offset and does not affect the global equilibrium: the macroeconomic equilibrium is stable. In contrast, when $S$ is different from I, sectoral disequilibrium translates into a global disequilibrium, which means that the macroeconomic equilibrium becomes unstable.

Within the scope of the neoclassical matrix, the equilibrium is systematically realized from the loanable fund market, based on a variation in the interest rate. When, for example, there is an excess supply of funds in relation to demand, savings are higher than investment: the interest rate decreases, and the substitution principle acts in such a way that investment increases until it equals savings. Consequently, in the neo-Ricardian perspective, the refutation of the substitution principle results in the systematic non-equalization of savings and investment, which implies the instability of the macroeconomic equilibrium and, ultimately, the refutation of Say's law (Herscovici, 2002).

\subsection{Convergence to the steady state}

The same type of observations can be made regarding neoclassical growth models. Automatic adjustments towards the steady state position, in Solow's model (1956), are carried out based on these mechanisms:

$$
\dot{k}=s . y-n k
$$

$\dot{k}$ represents the variation of $k ; s$, the propensity to save; $y$, the product per capita; and $n$, the growth rate of the active population.

The steady state $(\mathrm{k} *)$ represents the macroeconomic equilibrium: GDP per capita is constant, and the rate of growth of capital and labor, per capita, is equal to the rate of growth of the population, which corresponds to the full use of the factors of production. At this point " [...] the real return to factors will adjust to bring about full employment of labor and capital [...]" (Solow, 1956, p. 164). Using a CobbDouglas production function, the quantities of factors employed are determined from the equalization between their marginal cost and their marginal productivity, the returns to scale are constant and the law of decreasing marginal productivity is verified.

From (16), we can deduce that if $k$ value is different from equilibrium value, $k$ value will change to reach automatically the equilibrium position. Such equilibration mechanism may be explained in the following manner: in $k_{1}$, saving by worker is higher than the investment that corresponds to the steady state (Denis, 1974, p. 689): the interest rate decreases, investment increases: from the theory of loanable 
funds, investment and savings become equal., the capital stock increases until it reaches E. From the same mechanism, in $k_{2}, k$ will decrease until reaching the equilibrium position. It is thus possible to state that the theory of loanable funds fulfills the role of a stabilizer and allows for the realization of equilibrium.

Figure 2: The adjustment in the Solow's model

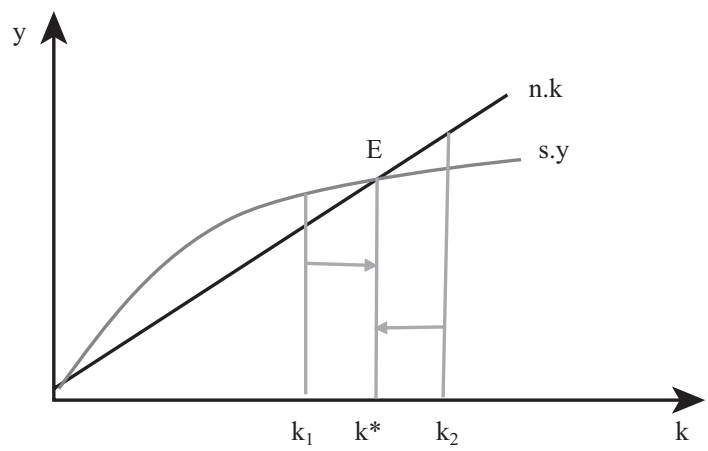

On the other hand, the law of decreasing marginal productivity allows explaining the slope of the s.y curve and thus justifying the stability of the equilibrium position (Solow, 1956, p. 167) ${ }^{5}$.

In the equilibrium position, global demand is equal to global supply, global savings to global investment, and variations in interest rates allow reaching the global equilibrium ${ }^{6}$. In the neoclassical macroeconomics, the loanable funds theory constitutes the mechanism that ensures the maintenance of equilibrium (Herscovici, 2013).

In Solow's model, equilibrium can also be represented by the following relationship:

$$
\text { G. } C=s=n
$$

$\mathrm{G}$ is the growth rate of the product; $\mathrm{C}$, the capital coefficient; $s$, the propensity to save; and $n$, the growth rate of the active population.

Relation (17) represents stable long-term growth conditions with full employment; in the Solow's model, this relation is always verified, based on the variations of $\mathrm{C}$, variations that are realized from the substitution principle (cf. equation $3^{\prime}$ ).

On the other hand, Harrod's instability is explained by the fact that $\mathrm{C}$ is constant, as well as the interest rate: as there is no monotonic relationship between the inter-

\footnotetext{
${ }^{5}$ On the contrary, in the models of endogenous growth, the marginal productivity of capital is constant or increasing, which justifies the existence of endogenous technical progress and prevents the system from achieving a steady equilibrium.

${ }^{6}$ I do not consider endogenous growth models as belonging to the Neoclassical Research Program: for example, the law of decreasing marginal factor productivity is not verified.
} 
est rate and the amount of capital., the fact that $\mathrm{C}$ (the capital / product ratio) is considered constant allows neutralizing the effects related to the reswitching of techniques (Herscovici, 2006), and thus ignoring the substitution principle.

\section{II) THE RESWITCHING OF TECHNIQUES: \\ A DEEPENING OF NEO-RICARDIAN CRITICISM}

\section{1) The traditional presentation}

\subsection{The fundamental mechanisms}

Initially, let's assume that the economy is divided into two sectors: sector 1 that produces consumer goods, and sector 2 that produces capital goods. We will choose the wage rate as unit of measure. We can write the following system in the following manner:

$$
\begin{aligned}
& 1=l_{a} \cdot w+c_{a} \cdot p_{c}(1+r) \\
& p_{c}=l_{c} \cdot w+c_{c} \cdot p_{c}(1+r) \\
& \text { (18) and }(19) \rightarrow \mathrm{w}=\frac{1-c_{c}(1+r)}{l_{a}+\left(l_{c} \cdot c_{a}-l_{a} c_{c}\right)(1+r)}
\end{aligned}
$$

$l$ and $c$ represent the quantities of labor and capital used, the indices $a$ and $c$ relate respectively to sectors 1 and $2, p_{c}$ is the price of a unit of capital., $w$ the price of a unit of labor, and $r$ the rate of profit.

Equation (20) shows that there is an inverse relationship between the profit rate $r$ and the wage rate, $w$.

This relationship is linear if $l_{a}+\left(l_{c} \cdot c_{a}-l_{a} c_{c}\right)(1+r)=0$, that is, if:

$$
c_{c} / l_{c}={ }^{c_{a}} / l_{a}
$$

\section{Proposition 4}

If (21) is verified, the relationship between $r$ and $w$ is linear (monotonic).

Figure 3: The profit/wages frontier: a linear relation $c_{c} / l_{c}=c_{a} / l_{a}$

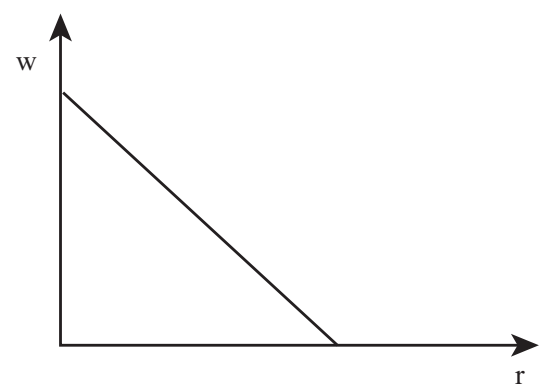




\section{Proposition 5}

If (21) is not verified, the relationship between $r$ and $w$ is not linear anymore.

Figure 4: The profit/wages frontier: a non- linear relation (1) $c_{c} / l_{c}=c_{a} / l_{a}$

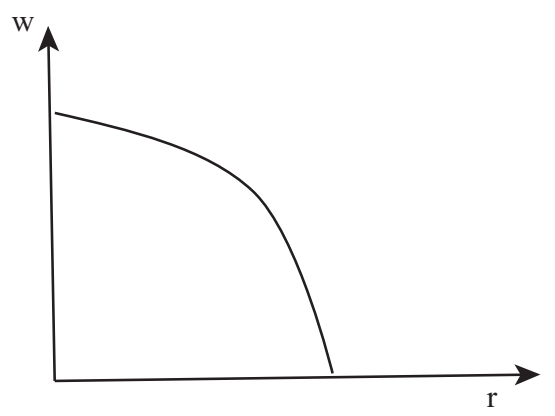

Figure 5: The profit/wages frontier: a non- linear relation (2) $c_{c} / l_{c}=c_{a} / l_{a}$

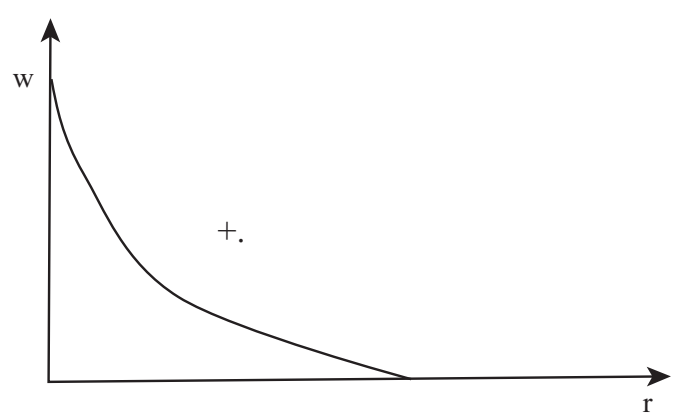

\subsection{The implicit hypothesis}

It is possible to conceive an amount of aggregated capital (Garegnani, 1970, p. 154, Harris, 1978, p. 231) regardless of the value of the distributive variables, only when $\mathrm{Ca} / \mathrm{la}=\mathrm{Cc} / \mathrm{lc}$.

The nature of the relationship between the wage rate and the profit rate depends on the capital / labor ratio in the two sectors, capital being valued in quantity (Ca / la and Cc / lc). Nevertheless, the necessary and sufficient condition to evaluate capital in quantity is that all capitals are homogeneous; in this case, the amounts of capital $\mathrm{Cc}$ and $\mathrm{Ca}$ are valued independently from the variation in the profit rate and the wage rate. The $\mathrm{C} / \mathrm{l}$ ratio in the two sectors determines the nature of the relationship between $w$ and $r^{7}$. We are in the presence of an economy that produces a unique good, from this same good and labor: the corn economy evoked by Ricardo.

\footnotetext{
${ }^{7}$ That is why Samuelson builds a pseudo production function in which "[...] the value of capital for each method was independent from the rate of profit (Robinson, 1980, p. 161).
} 
With regard to the neoclassical case, at the aggregate level, $\mathrm{Ca} / \mathrm{la}=\mathrm{Cc} / \mathrm{lc}$. As capital is valued in quantities of corn, these quantities do not depend on the variation of $w$ and $r$, and $\mathrm{Ca} / \mathrm{la}=\mathrm{Cc} / \mathrm{lc}$ for any value of $r$ and $w$. In other words, there is an equivalence between quantities and values (Herscovici, 2019).

The implications are as follows: when capital is heterogeneous, it is no longer possible to reason in terms of the quantities of capital. It is necessary to express this amount of capital in a common unit, that is, in value. In this case, the value of a given quantity of capital varies depending on the variation of $w$ and $r$; now, the variations of $r$ and $w$ determine the $\mathrm{C} / 1$ ratios. The Ricardian differential rent theory highlights the need to reevaluate capital in each period, when it is heterogeneous (Herscovici, 2019).

When capital is heterogeneous, it is not possible anymore to verify $\mathrm{Ca} / \mathrm{La}=\mathrm{Cc}$ / Lc, for all values of $r$ greater than 0 . In other words, the $\mathrm{Ca} / \mathrm{La}=\mathrm{Cc} / \mathrm{Lc}$ ratio will only be verified, for all positive values of $r$, if the economy produces a single good. This mechanism highlights the explanatory limits of the theories based on this hypothesis ${ }^{8}$.

\subsection{The different cases}

What are the implications regarding the choice of techniques? In the neoclassical case, that is, when $\mathrm{Ca} / \mathrm{La}=\mathrm{Cc} / \mathrm{Lc}$, the relationship between $r$ and $w$ is linear. The neoclassical case is a particular case, while the other cases are general.

\section{The neoclassical case}

When $\mathrm{Ca} / \mathrm{la}=\mathrm{Cc} / \mathrm{lc}$ is checked, there is a linear (monotonic) relationship between $w$ and $r$. This linearity is verified for the set of techniques, and there is only one point of return for the techniques. The capital / labor ratio (usually called $k$ ) depends directly on the relative price of the factors: when the price of capital (the rate of profit) increases in relation to the rate of wages, the more capitalistic techniques are substituted by less capitalistic techniques. There is thus a perfect substitution of the factors of production, for all values of $r$ (and, consequently, of $w$ ).

Figure 6: The neoclassical case: the verification of substitution principle

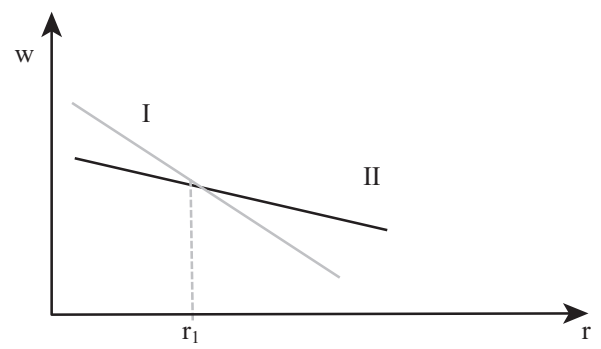

\footnotetext{
${ }^{8}$ For this reason, Solow (1956), in his growth model, considers an economy that produces a unique good.
} 
Without any ambiguity, technique I is the most capitalistic: it is for this reason that, when the profit rate increases, and exceeds $r_{1}$, this technique will be substituted by technique II, which is more labor intensive. The case that corresponds to the neoclassical hypotheses is a specific case, verified only when $\mathrm{Ca} / \mathrm{la}=\mathrm{Cc} / \mathrm{lc}$, that is, when it comes to an economy with a unique good (Deleplace, 2007, p. 472, Solow, 1956.)

Since goods and capital are heterogeneous, the equality between $\mathrm{Cc} / \mathrm{lc}$ and $\mathrm{Ca}$ / la is no longer systematically verified, which implies that the substitution principle is not verified for all positive $r$ values.

\section{The other cases: the "traditional" presentation}

In other cases, when $\mathrm{Cc} / \mathrm{lc} \neq \mathrm{Ca} / \mathrm{la}$, the relationship between $w$ and $r$ is not linear (monotonic). Such situations correspond to the following graphs (Hunt, 1981, p. 467):

Graph 7: Reswitching (1) (the non-verification of substitution principle)

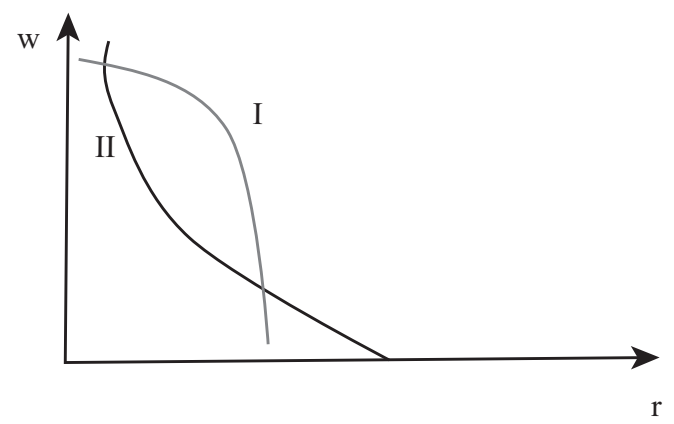

Graph 8: Reswitching (2) (the non-verification of substitution principle)

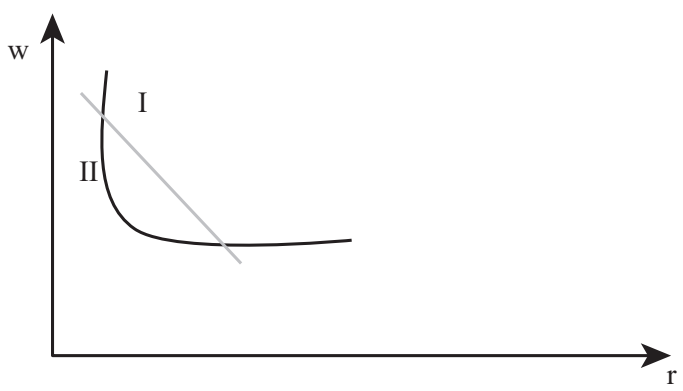




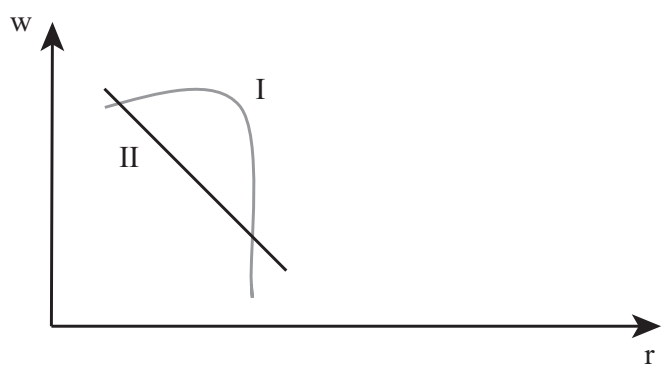

In all of these cases, there is more than one turning point for each technique. This means that, for some values of $r$, a given technique can be considered as the most capitalistic; and that, for other values of $r$, the same technique can be considered as the less capitalistic.

The capitalistic intensity is evaluated from the capital/labor ratio, represented by $k$. Neoclassical economists, starting with Marshall, consider that it is possible to measure a certain amount of heterogeneous capital., and that the value of this amount of capital is constant (Harris, 1978). On the other hand, the neo-Ricardian analysis showed that the value of this quantity of capital is not constant, but that it depends on the distributive variables, $w$ and $r$. It is the reason why the same technique, depending on the values of $r$, can be considered as the most or least capitalistic: as the value of $k$ changes when $w$ and $r$ changes, logically, it is not possible to determine the capitalistic intensity regardless of the level of $r$ and $w$. In this regard, Sraffa (1960, p. 100) speaks of a different economic system, due to the fact that "[...] there is no common basis on which a comparison can be made between both methods [...]. "

Thus, the cases represented in figures (7), (8) and (9), from the moment that capital is heterogeneous, contradict the relationship on which the neoclassical macroeconomics is based; the relationship between $w$ and $r$ is not monotonic.

\section{2) A Deepening of criticism}

\subsection{Some logical fallacies}

I will highlight some logical inconsistencies present in this traditional presentation; the resolution of these contradictions allows deepening the criticism that the neo-Ricardian economy formulates in relation to the neoclassical economy.

The substitution principle cannot be verified simultaneously, with regard to the aggregate level and the choice of techniques: when Hunt (1981, p. 463) considers the aggregate level, he considers the quantities of labor and capital used in production in terms of value (and not quantity). The logical error is as follows: at the aggregate level, the values of the capital employed in the two sectors cannot be constant when the distributive variables change, as specified in the choice of techniques.

If, at the aggregate level, $\mathrm{Cc} / \mathrm{Lc}$ and $\mathrm{Ca} / \mathrm{la}$ are equal., at the microeconomic 
level, each technique translates into a linear relationship between $r$ and $w$; but as $r$ and $w$ vary, according to the logic of the choice of techniques, Cc / Lc and Ca / la, in value, cannot remain the same. In this case, each technique can no longer be represented by a linear relationship between $r$ and $w$.

The case of neoclassical economics is a possibility among several others: it is verified only at a particular point, that is, for specific and unique values $(\mathrm{w} *$ and $r *)$. The reswitching of the techniques applies in all the other cases, that is, when $w$ and $r$ differ from $\mathrm{w}^{*}$ and $\mathrm{r} *$. It is important to note that there is no mechanism that ensures convergence to the equilibrium value represented by $\mathrm{w} *$ and $\mathrm{r} *$. Graphically, none of the techniques can be represented by a line, as shown in figures (8) and (9).

On the other hand, only one specific point is compatible with an exchange of techniques. We find a similar idea in Harcourt (1972, p. 43), when this author states that " [...] it is only at switch points that the wage and profit rate are the same for both methods so that any difference between their ks must be attributable to the productivities of the methods."

Apart from the case that corresponds to the production of a single good in the entire economy, the reswitching of techniques is the rule and simple switching cannot exist: the substitution principle cannot be verified simultaneously at the macro level and with regard to choice of techniques, for any value of $r$.

Due to the instability of the $\mathrm{Ca} / \mathrm{La}$ and $\mathrm{Cc} / \mathrm{Lc}$ ratios, the system that represents the choice of techniques can assume different configurations. Nevertheless, each of these configurations is, by nature, unstable, and changes depending on the variations of the distributive variables, which invalidates the substitution principle.

Finally, the following paradox appears: while the neoclassical economy, in its micro and macroeconomic foundations, presents itself as an exchange economy, its mechanisms are valid only in an economy that produces a unique good, that is, in an economy that, for nature, excludes exchange from its analysis (Pasinetti, 1975, Garegnani, 1970, Deleplace, 2007).

\section{Proposition 6}

The refutation of the law of marginal productivity and of the determination of factor prices based on their relative abundance (or scarcity) implies the refutation of the neoclassical theory of income distribution, for the following reasons: (a) as highlighted in relation (1), the distribution of income is determined from the quantity of factors multiplied by their prices (b) the concept of quantity is meaningless when capital is heterogeneous and (c) prices do not correspond to the marginal productivity. Consequently, the neoclassical theory of income distribution is completely refuted. 


\section{Proposition 7}

The concept of quantity cannot be applied when it comes to aggregating heterogeneous capital and, consequently, the law of decreasing marginal productivity is incompatible with the reswitching of techniques: as the relative quantities of the factors determine their marginal productivity, it is logically impossible to reason in terms of quantities: the reswitching of techniques leads to the refutation of this law.

In the neoclassical economy, scarcity is conceived as the ratio between the respective quantities of the factors of production. In the neo-Ricardian approach, scarcity is essentially social., as opposed to its natural and universal dimension; social., because the capital / labor ratio is determined by the value of the distributive variables, and not by a "natural" scarcity, evaluated in physical quantities.

Here we find the fundamentals from which neo-Ricardian economists elaborated their criticisms of neoclassical economics: on the one hand, the substitution principle shows that prices determine quantities. On the other hand, the law of decreasing marginal productivity indicates that relative quantities determine prices.

Relation (6) contains two unknowns, $r$ and $k^{9}$. It is not possible to solve a system in which the number of unknowns is greater than the number of equations. It is for this reason that neo-Ricardian economists consider that the distributive variables $(w$ and $r$ ) are determined in an exogenous way. These variables determine the value of the quantities of factors of production and, consequently, wages and profits are not determined based on the existence of a labor market or a market for loanable funds (Herscovici, 2019).

\subsection{An alternative analysis}

Relation (6) is incompatible with the substitution principle: if $d r$ increases, for example, $k$ increases, which is contrary to the substitution principle. The reswitching of the techniques allows refuting the relations (3) and (3'). Likewise, it is incompatible with (4) and (6). We can observe, according to the previous observations, that (3) is not verified: in this case, (4) and (6) cannot be verified either.

Apart from the case in which the economy produces a unique good, it is not possible to verify simultaneously the basic relations of neoclassical macroeconomics, using equations ( $\left.3^{\prime}\right),(4),(5)$ and (6), that is, it is not possible to verify simultaneously the perfect substitution of the factors of production, the remuneration of these factors to their marginal productivity and the law of decreasing marginal productivity (Deleplace, 2007, p. 474 and following). Neo-Ricardian analysis provides coherent elements to elaborate a radical critique of the Neoclassical Research Program, with regard to its microeconomic foundations; this criticism extends to the macroeconomic level.

In neoclassical framework, the price is determined by the interaction of supply and demand. On the other hand, supply itself is determined from the law of decreas-

\footnotetext{
${ }^{9}$ As $r$ depends on $w$, we can consider $w$ and $k$ as unknowns.
} 
ing marginal productivity, and the factors of production are remunerated according to the prices that depend on this same law. As this law is no longer verified, supply and demand are no longer able to explain the formation of prices in the market (Sraffa, 1925, p. 280)

In this case, the theory of labor value is an alternative interpretation to explain the formation of value and prices. In the tradition of Classical Economics, from Smith to Ricardo and Marx, the value is determined from the costs of direct and indirect labor; supply and demand are not explanatory, insofar as they explain only the momentary deviations between market prices and natural prices (or production prices, for Marx).

The paradox is as follows: the neoclassical school refutes the theory of labor value, based on the fact that this theory would not be able to explain the formation of prices, when the capital / labor ratios are different in different sectors. Nevertheless, it is possible to solve this problem of transforming values into prices, based on the Marxist or neo-Ricardian matrix. In this regard, Marx (1976 [1872]) shows (a) that, at the sectoral level, in the general case, prices have to be different from the values; (b) that this price / value deviation is not random, but systematic and; (c) that, on an aggregate level, all prices are equal to all values (Herscovici, 2002).

On the other hand, the reswitching of the techniques shows that this same criticism applies to the neoclassical economy: in the neo-Ricardian view, the neoclassical construction is coherent only when the organic compositions of the two sectors are equal., that is, when the capital / labor ratios are the same (Samuelson, 1962 , p. 196.). Within the scope of the thesis presented in this study, the neoclassical case is even more restricted: apart from an economy with a single good, the neoclassical case can only be verified for specific values of $r$ and $w$, this equilibrium being unstable, by nature.

\section{FINAL REMARKS}

The main conclusions can be summarized as follows: the law of decreasing marginal productivity of factors of production, the perfect substitution of these factors according to their prices and the remuneration of these factors at their marginal costs represent the pillars on which neoclassical macroeconomics was built. The necessary and sufficient condition to justify these hypotheses is that it is possible to conceive and evaluate a quantity of aggregate capital independently from the distributive variables, which corresponds to the substitution principle.

The refutation of these hypotheses implies the refutation of the entire architecture of the standard neoclassical macroeconomics and of its main results:

i) The remuneration of the factors of production can no longer be explained based on their respective contributions to production (Clark, 1891). As soon as the distributive variables are exogenous, there is no longer a labor market or a capital market in which factors are remunerated according to their marginal productivity: it is the whole neoclassical theory of income distribution that is being refuted. 
ii) This criticism also shows why the convergence mechanisms towards a stable equilibrium position can no longer operate, and thus allows the construction of dynamic growth models that highlight the structural instability of the system, Harrod's model being one of the first attempts (Herscovici, 2006).

The neo-Ricardian criticism used in this work constitutes "[...] a pure case of refutability, in the sense defined by Lakatos" (Jorland, 1995). Contrary to Popper's epistemology, this refutation is theoretical., not empirical: it highlights the internal inconsistencies of the neoclassical macroeconomic model.

The Neoclassical Research Program fails to resolve its internal contradictions. Samuelson himself (1962) admitted it. Even so, he continued to use what certain economists called the "neoclassical parable" (Harris, 1978, p. 240): capital is conceived, by hypothesis, as a homogeneous substance that can be measured regardless of the value of distributive variables.

This criticism highlights the epistemological fragility of the (microeconomic) bases on which the neoclassical macroeconomics was built; it also allows rejecting the law of supply and demand as a determinant of value (Sraffa, 1925), and the empiric explicative power of functions built from such hypotheses (Felipe, McCombie, 2005, Herscovici, 2019).

\section{REFERENCES}

Amadeo Edward J, Dutt Amitava Krisna, (1987), “Os keynesianos neorricardianos e os pós-keynesianos”, Pesquisa e Planejamento, 17 (3), dez. 1987.

Carvalho, Fernando Cardim de, (1983) "On the concept of time in Shacklean and Sraffian economics", Journal of Post-Keynesian Economics, Winter 1983-84, vol. VI, n²: 265-280.

Clark, J.B., (1891), "Distribution as determined by a law of rent", Quarterly E Journal of Economics, 5 (April), 289-318.

Deleplace Ghislain, (2007), Histoire de la Pensée Économique, Paris: Dunod.

Denis, Henri, (1974), Histoire de la Pensée Economique, Paris: Presses Universitaires de France.

Felipe Jesus, McCombie, J.S.L., (2005), “How sound are the foundations of the aggregate production function?” Eastern Economic Journal., vol. 31, no. 3, Summer: 467-488.

Garegnani Pierangelo, (1980) Sobre a teoria da distribuição e do valor em Marx e nos economistas clássicos, Progresso técnico e teoria econômica, Hucitec-Unicamp, São Paulo, 1-38.

Garegnani Pierangelo, (1970), "Heterogeneous capital., the production function and the theory of distribution". Review of Economic Studies, 37: 407-436.

Harcourt G.C.,(1972), Some Cambridge controversies in the theory of capital., Cambridge: Cambridge University Press.

Harris, Donald, (1978), Capital., Accumulation and Income Distribution, Stanford, CA: Stanford University Press.

Hayek, F.H., 2009[1950], The pure theory of capital., The Ludwig von Mises Institute, Auburn, Alabama. 
Herscovici, Alain, (2002), Dinâmica Macroeconômica: uma interpretação a partir de Marx e de Keynes, São Paulo: EDUC/EDUFES.

Herscovici, Alain, (2006), "O modelo de Harrod: natureza das expectativas de longo prazo, instabilidade e não linearidade”,Economia e Sociedade (UNICAMP), Campinas, v. 15, n.26: 29-55. Herscovici, Alain, (2013), "Keynes e o conceito de capital: reflexões epistemológicas a respeito das premissas sraffianas da Teoria Geral”, Revista de Economia Política, vol. 33, n 3 (132), julho-setembro: pp. 486-504.

Herscovici, Alain, (2019), Essays on the Historicity of Capital., New York: Palgrave Mac Millan.

Hunt, E.K., (1981), História do Pensamento Econômico, Rio de Janeiro: Editora Campus.

Jorland, Gérard, (1995) Les paradoxes du capital., Paris: Editions Odile Jacob.

Marx, Karl, (1976, [1872]) Le Capital., Critique de l'économie politique, Editions Sociales, Paris, Livre III, 1976.

Marcuzzo Maria Cristina and Rosselli Annalisa, (2011), "Sraffa and his arguments against 'marginism'”, Cambridge journal of Economics 35, 219-231.

Pasinetti, L., (1975), Lezione di teoria della produzione, Bologna.

Petri Fabio, (1998) "The "Sraffian" critique of neoclassical economics: some recent developments", Revista da Sociedade Brasileira de Economia Política n. 3, dezembro de 1998, Rio de Janeiro: 5-44.

Ricardo, David, (1821), On the Principles of Political Economy and Taxation, Third Edition, Batoche Book 2001, Ontario.

Robinson, Joan, (1953-1954), "The Production Function and the Theory of Capital”, Review of Economic Studies, 21(2), 81- 106.

Robinson, Joan, (1980), Further Contributions to Modern Economics, Oxford: Basil Blackwell Publisher.

Samuelson, P. A., (1962), “ Parable and Realism in Capital Theory: the Surrogate Production Function “, Review of Economic Studies (June 1962).

Solow, Robert, (1956), "A contribution to the theory of economic growth", Quarterly Journal of Economics, vol. 70, pp. 65-94.

Sraffa, Piero, (1925,) "Sulle relazion ifracosto e quantitá prodott.a”. Annali di Ecónomia, vol. II, no.1, pp. 277-328.

Sraffa, Piero, (1926), “The Law of Return Under Competitive Conditions”, The Economic Journal 36 (144) (December), 277-328.

Sraffa, Piero, (1960), Production of Commodities by Means of Commodities: Prelude to a Critique of Economic Theory. Cambridge: Cambridge University Press. 